\title{
Control creep and the multiple exclusions faced by women in low-autonomy sex industry sectors
}

\author{
Susan Dewey' \\ Isabel Crowhurst ${ }^{2}$ \\ Tiantian Zheng ${ }^{3}$ \\ Thaddeus Blanchette 4 \\ 'University of Alabama, Tuscaloosa, AL, USA \\ ${ }^{2}$ University of Essex, University of Essex, United Kingdom \\ ${ }^{3}$ SUNY Cortland, NY, USA \\ ${ }^{4}$ Instituto de Biodiversidade e Sustentabilidade, Universidade Federal do Rio de Janeiro, \\ Macaé/RJ, Brasil
}

\begin{abstract}
This article unites the co-authors' years of empirical research with women in policed, stigmatized, and low-autonomy sex industry sectors in Brazil, China, Italy, and the United States to identify six prevalent forms of exclusion: economic, intersectional, health, safety, public vilification, and policing. We analyze the distinct manifestations of these exclusionary forces in all four sites to introduce criminal creep as theoretical shorthand for the global seepage of ideological, structural, and interpersonal exclusionary forces into social life, professional practice, and socio-legal procedures that marginalize women in the sex industry as victimcriminals in need of rehabilitation. Uniting and building upon literature on feminist engagement with and critiques of citizenship, conceptual uses of "creep", carcerality and crimmigration, and critical anti-trafficking studies, we argue that criminal creep facilitates a perfect storm of exclusion that promotes sex workers' de facto and de jure exclusion from citizenship through a set of wide-ranging set of harms. Furthermore, we identify "control creep" as a factor limiting - even radically - the political organization of and social scientific production regarding the vulnerable populations anti-sex work and anti-trafficking laws are supposedly designed to aid.
\end{abstract} Key words: sex work, prostitution, anthropologies of repression. 


\section{A capilaridade de controle e as exclusões múltiplas encaradas por mulheres engajadas em setores da indústria sexual de baixa autonomia}

\section{Resumo}

O presente artigo reune os anos de pesquisas empíricas feitas pelos co-autores com mulheres policiadas, estigmatizadas, e de baixa autonomia em setores da indústria sexual no Brasil, China, Itália e Estados Unidos. Identificamos seis formas de exclusão social prevalecentes nestes campos: econômica, de saúde, segurança, difamação pública, intersetorial, e policiamento. Analisamos as manifestações distintas dessas forças excludentes nos quatro países estudados para apresentar "control creep" - ou a criminalização sorrateira - como espécie de abreviação teórica que significa a infiltração global de forças ideológicas, estruturais e interpessoais excludentes na vida social, nas práticas profissionais e nos procedimentos sócio-legais que marginalizam as mulheres na indústria do sexo, as situando como vítimas-criminosas que precisam de reabilitação. Unindo e desenvolvendo a literatura sobre o envolvimento feminista com e as críticas feministas de cidadania, os usos conceituais de "capiliaridade", carceralidade, a criminalização da migração e os estudos críticos sobre o tráfico human, argumentamos que a criminalização sorrateira facilita a criação de uma "tempestade perfeita" de exclusão, que promove a exclusão de fato e de jure das trabalhadoras do sexo da cidadania através de um conjunto abrangente de danos. Além disso, identificamos a "criminalização sorrateira" como um fator que limita - até radicalmente - a organização política de e a produção científica social sobre as populações vulneráveis que as leis anti-trabalho e anti-tráfico foram supostamente projetadas para ajudar.

Palavras-chave: trabalho sexual, prostituição, antropologias sobre repressão. 


\title{
Control creep and the multiple exclusions faced by women in low-autonomy sex industry sectors
}

\author{
Susan Dewey \\ Isabel Crowhurst \\ Tiantian Zheng \\ Thaddeus Blanchette
}

\section{Introduction}

An extensive body of literature across a wide variety of academic disciplines employs the notion of "creep" in reference to the gradual expansion of particular ideological forces - state-sponsored or otherwise- into diverse and often subtle aspects of everyday social interaction. This article expands this existing literature by introducing control creep as theoretical shorthand for the unrelenting expansion of punitive socio-legal measures that marginalize women in low-autonomy sex industry sectors. Our focus here is on what control creep does with respect to its problematic and complex effects on its targets, with particular respect to the driving forces and contexts underpinning the pervasive creep of criminalization and control measures. We accordingly engage with expanding scholarship that analyses the criminalizing agenda in the regulation of commercial sex as a strengthening global trend, and draw on four case studies-China, Italy, the United States, and Brazil- to highlight ways in which control creep results in at least six strikingly similar forms of harmful exclusion among women in all four countries' low-autonomy sex industry sectors: economic, intersectional, health, safety, public vilification, and policing (See "Table" for a tabular representation of our findings). We also emphasize how control creep's contemporary manifestations are reinforced by heightened popular anxieties about security in Europe, Asia, and the United States. These anxieties take numerous forms, including militia/ police control of prostitution in Brazil, anti-migrant/racist politics and anti-trafficking policies in Italy and Europe more generally, the war on drugs and racialized "tough on crime" measures in the United States, and anti-migrant and anti-trafficking campaigns in China. 


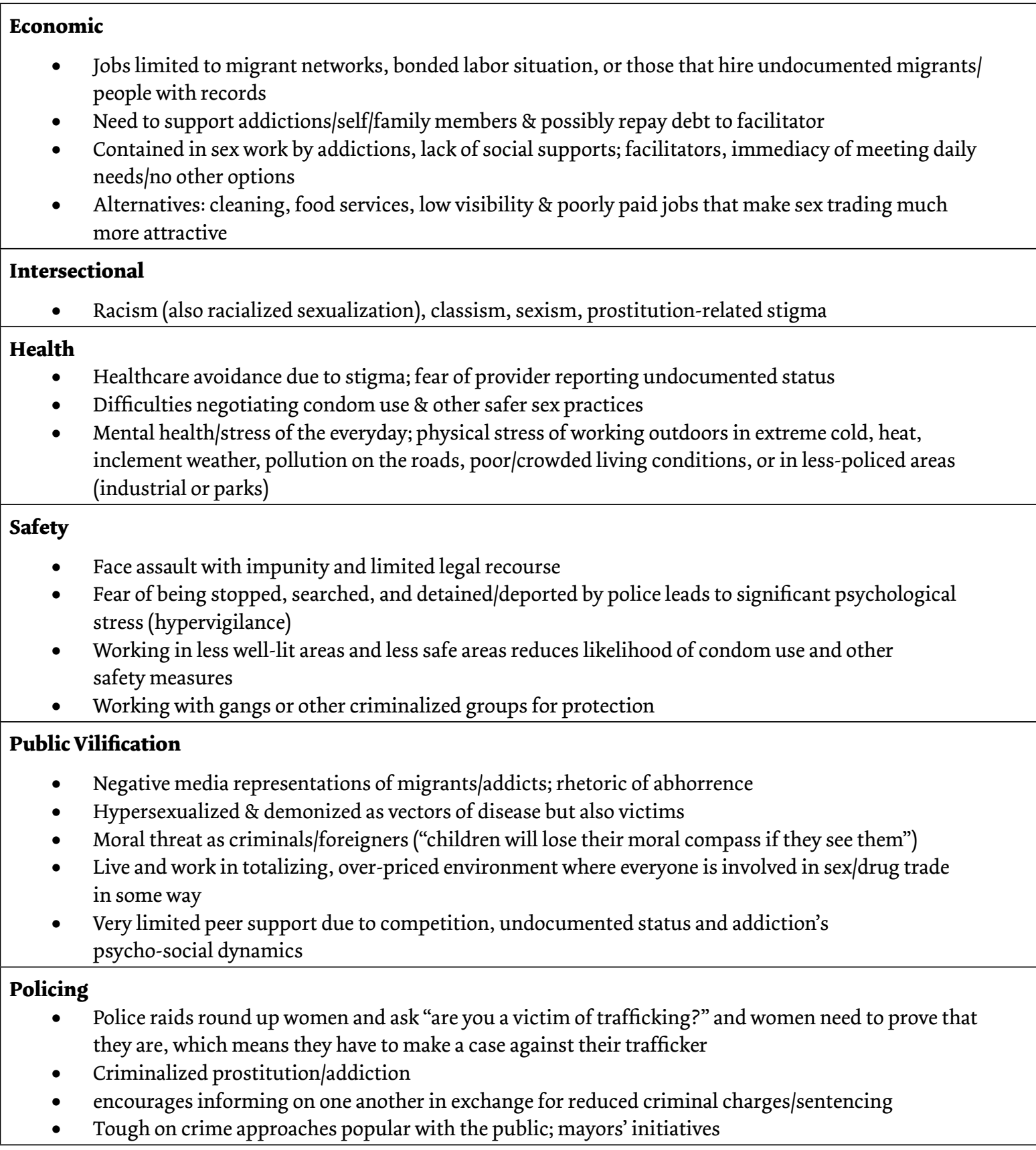

In all four regions, the performative powers associated with global anti-trafficking agendas discursively position women in prostitution as victim-criminals in need of rehabilitation and/or re-education. Hence women who use prostitution as a means to navigate multiple marginalities not only face socio-legal scrutiny as criminalized "prostitutes" (often "foreign prostitutes"), "addicts," "street people," or unwanted migrants, but also as victims who require therapeutic and/or tutelary intervention. Given this range of systemic and interpersonal modalities of control directed at the women, we contend that control creep generates a totalizing exclusionary force through which women from marginalized communities experience severe limitations on their socioeconomic opportunities. This, in turn, impels them into low-autonomy sex industry sectors where they face significant stigma that results in over-policing and compromised health and safety. We offer a unique contribution to literature that has identified the global trend in expanded sociolegal and related measures by acknowledging the synchronous operations of law and policy endorsed by a general public supportive of 
sex workers' stigmatization, and the enforcement of various socioeconomic exclusions at the interpersonal level during interactions between sex workers and street-level bureaucrats tasked with the enforcement of related laws and policies. We argue that control creep undermines sex workers' agency through systematic socioeconomic exclusion that requires these multiple levels of collusion, which occur with striking consistency across the authors' four very different cultural contexts.

As worrisome is the fact that all four authors, engaged in street- and brothel-level research with sex workers and sex worker activist groups over the past two decades, have noted that police and legal activities surrounding control creep have made it increasingly difficult for sex workers to organize themselves and make their needs understood to policy makers. It has also limited social scientific researchers' ability to interact with these populations. Control creep is thus implicated in creating a self-fulfilling prophecy regarding sex-working women. By squelching these women as political agents and threatening their allies and interlocutors in civil society, it (re)produces as social reality the stereotype of the "powerless victim/criminal" in need of tutelary intervention and rehabilitation. This situation has become increasingly acute with the intensification of the post neo-liberalism, militarized capitalism, and parahumanitarian policies (Amar, 2013) that make up what has been conventionally termed the "turn to the right" in the global political scene - a situation that has concretely manifested itself in all four countries studied here.

\section{Literature review}

Analysis presented here adds a new dimension to the multi-disciplinary usage of "creep", a term connoting stealth in the form of a slow-moving, subtle, pervasive, and often-unnoticed yet inevitable phenomenon, as opposed to an ostentatious event. Chuang (2014), for example, uses the term to examine "exploitation creep" in U.S. anti-trafficking legislation focused on eradicating "slavery" while failing to advocate for labor and migrant rights, and Rathod (2015) employs "crimmigration creep" in reference to expanded legislation that prevents those with criminal records from entering the United States. Carver (2014) uses "control creep" to characterize the normalisation of state security measures that criminalise public protests, and Fox (2014) employs "interest creep" as shorthand for the mobilisation of vague concerns (such as "national security" or "child protection") to justify morality-based judicial decision-making. Researchers have also used "creep" to express concerns about the expansion and dilation of cultural meanings attached to vulnerability with respect to the criminalization of HIV transmission ("criminalization creep", Dej \& Kilty, 2012), expanding victimization to encompass a wide range of previously normalized experiences, such as bullying ("concept creep", Haslam 2016), and the widespread growth of therapeutic discourse and practices to address university students' ostensibly fragile psycho-social wellbeing ("vulnerability creep”, Ecclestone, 2017). As this brief overview reveals, "creep" derives its semantic power across a variety of literatures in otherwise unconnected disciplines from an implied sense of powerlessness vis-à-vis totalizing change. This change, as we also discuss in this contribution, "creeps in" through the, sometimes almost imperceptible, normalization of reductionist and ideologically-driven paradigms, policies and practices at the hand of political forces and social institutions that initiate and then drive such change.

The unrelenting and increasingly diffused expansion of socio-legal measures aimed at controlling sex workers' bodies and lives has been identified as a global trend in a growing body of scholarship in criminology, socio-legal and policy studies among others (Sanders and Campbell 2014; Dewey, Crowhurst, and Izugbara, 2019). These scholars' examinations of expanded criminal justice oversight ostensibly designed to reduce instances of coerced prostitution emphasize the resulting exclusionary measures that reduce women's opportunities to migrate, earn an income, or receive services they regard as meaningful (Pickering \& Ham, 2014; Jahnsen \& Skilbrei, 2017). In a recent contribution, for example, Graham (2017) usefully applies Simon's 
(2007) concept of 'governing through crime' to delineate ways in which criminal law is deployed to manage and control sex work and to justify punitive interventions in this area also through other policy measures, including immigration laws and border control. Hence Graham argues that "by framing sex work as an issue of crime, with sex workers being both the perpetrators of crime and the potential victims of exploitative crime, the state is able to legitimize its actions against sex workers, while ignoring the harm done to sex workers by the state" (2017, p. 202).

Similarly, Jahnsen and Skilbrei (2017) argue that a 'crimmigration' approach, i.e. one that combines immigration and criminal laws is being adapted to target more efficiently prostitution markets that in Norway are rapidly changing as a result of globalization. Whilst the aims of these measures are seemingly to protect women from trafficking, they end up legitimizing their constant exposure to surveillance and "police intervention in the prostitution market and in the lives of those who sell sex, and for many this has meant that they have lost their homes and deposits, and have been subjected to widespread discrimination by landlords and hotels" (Jahnsen and Skilbrei 2017, 269). Outlining similar developments, Scoular and Carline (2014) use the notion of "creeping neo-abolitionism" to characterize the spread across Europe of a reductive victim/victimizer paradigm that drives many criminal justice initiatives to abolish prostitution. In this context, women's agency is left unrecognized while "the rhetoric of victimhood consolidates and legitimizes law's power over women's bodies, foreclosing any discussion of forms of rights or recognition that could support counter-hegemonic challenges (Scoular and Carline, 2014, 622). Researchers also argue that a shift to coordinated law enforcement and social services responses in many countries' prostitution-related regulatory regimes is little more than window dressing which only increases the exercise of state oversight in sex workers' lives (Phoenix, 2009; Scoular \& O'Neill, 2007) and inadvertently harms the very women such responses purport to assist, as has been argued in the case of anti-trafficking raids (Ditmore \& Thukral, 2012). Even policies targeting prostitution that are viewed as examples of 'progressive governance' and part of benign rehabilitative efforts mask attempts to increase social control "under the rhetoric of inclusion, through techniques of risk and responsibilization" (Scoular and O'Neill 2007, 764). In this respect, Munro contends that the implementation of international law regarding trafficking, in the form of the United Nations Palermo Protocol, "may ultimately have produced a duplicitous response that permits its provisions to be manipulated in line with domestic agendas of border integrity and the suppression of vice" (Munro, 2006, p. 332). Scholars in this field have also been critical of initiatives that target particular sex industry participants, such as minors (Musto, 2016) or men who purchase sex (Ellison, 2015), because of the way that moralizing, rescue-based approaches predominate at the expense of meaningfully considering the deeper socio-structural issues that inform these participants' decision-making.

While the intersections between social, legal, and economic forms of exclusion are apparent, in various ways, in the work of these scholars, researchers have not yet sufficiently theorized the totalizing impacts of these exclusions on sex workers. It is insufficient to examine the impacts of law and policy on women in sex work when, for instance, the experiences with poverty and violence endemic to the lives of women in lowautonomy sex industry sectors may be more important to the women than the legal status of prostitution. Likewise, studies that only critique the prevailing socio-legal focus on trafficking-often to the exclusion of sex worker rights discourse - fail to account for the reality that women in low autonomy sex industry sectors may indeed feel coerced into their work by force of circumstance.

The present article engages with and expands upon this existing work in its analysis of the quotidian operations of control creep in four very different sex industry contexts, emphasizing how these increasingly diversified socio-legal control mechanisms impact sex workers as they internalize and/or mobilize against six primary forms of exclusion - economic, intersectional, health, safety, public vilification, and policing - in the course of their everyday lived experiences. 


\section{Globally Charting Control Creep: Four Case Studies}

Following Jo Phoenix's (2017) call to locate contingent phenomena at work in prostitution within broader global context, we united our research conducted in four very different sex industry sectors to demonstrate how control creep operates in sex workers' lives cross-culturally. This approach emphasizes the regulation and governance of sex work as part of global governance by moving beyond context-specific analyses to highlight significant experiential and socio-institutional similarities that result from the criminalization of prostitution across cultural and geographic divides.

Reflecting on their twenty years of research experience with women in the sex industry while working together on a major international project on the sex industry that united 77 contributors from all over the world - the Routledge International Handbook of Sex Industry Research - gave the authors pause for reflection on the disciplinary and geographic silos that characterize sex industry research. These silos typically isolate or otherwise compartmentalize research findings as somehow unique to particular contexts, sometimes in ways that inhibit theorizing about globally pervasive phenomena. The authors' respective long-term ethnographic engagement in four specific contexts-Brazil, Italy, China, and the United States- provided unique insights into the particularities of geographical and cultural context as well as the similarities they noted in each other's previously published work. Working together in-person and by Skype in 2017, the co-authors reviewed the findings in each other's research and ascertained the existence of the six exclusionary forces identified here through extensive conversations about the specificities of each author's field site. Uniting the four studies' findings demonstrates how control creep operates by producing particular effects that are contextualized manifestations of a global issue.

Results presented here do not derive from a systematically comparative study, yet we contend that this fact makes the striking similarities between how women experience exclusion all the more relevant. Despite some differences in methodological approach, the four authors' respective research designs shared much in common. ${ }^{1}$ All four authors engaged in participant-observation ethnography in low autonomy sex industry sectors occupied by women struggling with numerous forms of socioeconomic exclusion. Women in the Brazilian case (which focuses primarily on Rio de Janeiro) tend to be from the (non)working classes of the city's suburbs and favelas, many of whom are drawn into prostitution as an economic solution following failed "traditional" partnerships with male breadwinners who subsequently abandon them and their children.

\footnotetext{
Thaddeus Blanchette has lived in Rio de Janeiro for 20 years and has conducted street-level ethnographic research in that city's brothels and street scenes since 2005. He has been an active participant in and academic ally to sex worker organizations, helping represent them at the municipal, state, and federal level in anti-trafficking policy-making groups. His research and affective partner is currently president of Brazil's oldest sex worker association. Tiantian Zheng lived and worked as a low-tier karaoke bar hostess in Dalian, a city in Northeastern China, which allowed her access to hostesses' social networks, including their friends, siblings, romantic partners, paying clients, and men who protected them in exchange for sexual services. Isabel Crowhurst resided at shelters for migrant women leaving sex work in Italy, where she immersed herself in the everyday operations of government-funded organizations attempting to assist victims of sex trafficking. Susan Dewey lived in both a U.S. transitional housing facility for women leaving street prostitution and the neighborhood street contexts in which street-based sex trading, and the illicit drug economy it supports, occurs.

The authors also interviewed a variety of actors. Blanchette conducted open ended interviews with sex workers, their domestic partners and other family members, clients, bouncers, brothel owners and managers, police officers and an array of social workers and NGO members who interact with those who sell sex, as well as local and federal policy makers involved in the overhauling of his country's anti-trafficking laws. Zheng conducted open-ended interviews with hostesses, their clients, family members, medical doctors, police officers, and government officials whose decisions impact the women's lives. Crowhurst interviewed support staff at organizations that provided support to women in prostitution, including lawyers, social workers, cultural mediators, peer workers, volunteers, and managers. Dewey interviewed women with current and past histories of street prostitution and the criminal justice, social services, and healthcare providers who regularly interact with the women.

During the same period indicated above, the four authors engaged with a variety of documentary and archival resources. Blanchette conducted historical research into prostitution at the State Archives of Rio de Janeiro and the Brazilian national archives. He has maintained a database regarding media treatments of sex work in Brazil for 15 years. He is also involved in intense participant-observation research with the various governmental committees set up to combat trafficking in Brazil and redefine Brazil's laws so that these would be in accordance with the Palermo Protocols. Zheng closely followed media and other popular cultural accounts of hostesses' lives. Crowhurst engaged in documentary analysis of policies, bills, jurisprudential rulings, and political statements pertaining to the governance of prostitution in Italy. Dewey reviewed case file data at the transitional housing facility, reports and other documentary materials produced by criminal justice and social service professionals, and legislation related to the governance of prostitution.
} 
Women in the Italian case study are primarily undocumented migrants who do not have the right to legal work, and are the targets of widespread xenophobia and racism. Hostess bar workers in China are women from rural areas who have migrated to the city without a residence permit and associated legal right to work and face widespread discrimination from urbanites who regard them as uncouth villagers. The disadvantages faced by U.S. women in street prostitution include inter-generational poverty, addiction, compromised health, exclusion from housing and legal work as a result of criminal convictions, and the structural violence of racism.

The following four case studies derived from our research with women in policed, stigmatised, and lowautonomy sex industry sectors demonstrate how control creep manifests in quite similar ways despite otherwise significant cultural differences between Brazil, China, Italy, and the United States.

\section{Case Study One: Brazil}

Brazil is a qualitatively different from the other three case studies presented in this article because the sale and/or purchase of sex never been criminalized nor officially regulated in that country. This has led to the wide-spread, global perception that prostitution is "legal" in Brazil'. In fact, as has been pointed out elsewhere (Blanchette; Scettini, 2017, it's better to think of it as "not necessarily illegal". While formal legal controls over the sale and purchase of sex in Brazil are few, they are purposefully written in such an open and vague fashion that they can be situationally applied by street-level police officers and precinct commanders to promote the effective control and even regulation of prostitution (Blanchette, et al, in press). Police and government officials are and historically have been involved in the oversight and control of prostitution in Brazilian cities for over a century in what might be termed a system of "non-regulated regulation".

An example of how this has worked can be seen in early twentieth century Rio. As historian Cristiani Schettini remarks, late 19 th and early $20^{\text {th }}$ century authorities in the city resisted the French and Argentinian model of prostitution regulation in closed houses and became an early supporter of abolitionism, following on the successful campaign to abolish slavery in Brazil (Schettini, 2006). However, as the League of Nations' undercover investigator into human trafficking, Paul Kinsie, reported in 1924:

[N]o man or woman can operate a house of prostitution. A woman can, however, upon securing a license, conduct a boarding house, known as a pensao [sic], for prostitutes. The housekeeper may have as many prostitutes in her house as she has rooms, and may charge the prostitutes any amount that she sees fit for room and board. The housekeeper cannot share in the prostitutes' earnings.... The housekeeper keeps a register of all inmates, which includes name, age, nationality, etc. This register is submitted to the local Police Precinct each time a new girl is registered, or a girl departs. (Kinsie, apud Chaumont, et al 2017).

In this way, the city authorities of Rio de Janeiro established what were effectively brothels, which paid a licensing fee, registered women, and were under police supervision without ever, officially, regulating prostitution. It is notable in this context that "pensão" merely means "boarding house" in Portuguese and at this time (the early 1920s) any female boarding house in Rio was legally treated as a brothel by authorities, whether or not its boarders sold sex.

While each city in Brazil has a different local story of administering prostitution, Rio - the ex-capital - has served as a template for the rest of the country. Over the decades, the police's direct or formal control over the sex trade in Rio has waxed and waned according to the political winds, occasionally punctuated with brief outbursts of abolitionist fury and attempts to close down the sex trade for good (Pereira, 2003).

\footnotetext{
2 As a thermometer of popular perceptions of the world, Wikipedia is quite useful. The entry on Prostitution in Brazil is particularly revealing of the common-sense notion that "prostitution is legal in Brazil". Any number of other affirmations of this sort can easily be found by searching for "prostitution" and "Brazil" on the internet.
} 
Typically, these efforts have only served to spread prostitution to other areas of the city without eliminating it in the older districts. Historical research has not been able to uncover any neighborhood in Rio were prostitution was quashed, once established (Schetinni, Blanchette, 2017). Indeed, in the early 'oos, the local sex workers' rights group, Davida, was located in the middle of what had been the city's slave brothel district in the 1840s, an area that today is plied by mostly late-middle aged hotel-working street walkers. In this sense, Rio de Janeiro has not yet been successful in implementing the "urban cleansing" schemes carried out in other countries like the U.S. or Italy, which have pushed prostitutes out to the peripheries and highways.

Evidence gathered by Thaddeus Blanchette and his co-researchers over the past 15 years suggests that the reason for this "failure" is the profit sex work remits to factions within the police and their paramilitary allies, commonly referred to as "militia". As many brothel owners and managers have told him, "You can't run a puteiro in Rio without police partnership". Thus, in spite of brothels being formally criminalized by the Brazilian penal code, Blanchette found close to 300 venues where sex is sold in Rio in 2009, more than 2/3rds of which were establishments identifiable as illegal under Brazilian prostitution laws. In such a scenario, it is difficult to clearly claim that Brazilian laws criminalize, decriminalize, regulate, or deregulate prostitution. It is better to say that the vagueness of the Brazilian penal code with regards to prostitution is not a "bug" but rather a "feature", allowing police and other municipal authorities the maximum amount of leeway in dealing with sex work. Unlike prohibitionist countries like the U.S. or China, the law does not commit authorities to repressing prostitution: like Italy, they have enough laws surrounding prostitution that they can go after any given establishment, street scene, massage parlor, or escort service they choose, if these upset the local bourgeoisie or do not pay the arrego - the informal tax police charge all sex working establishments.

Rio's contemporary system for dealing with prostitution is thus surprisingly similar to that documented by Kinsie in the 1920s, with the caveat that the arrego is now formally illegal (although practically universal). Women are allowed to work unharassed in police designated spaces as long as local residents are kept happy and money flows to the authorities. Today's "saunas", "massages", "nightclubs", and "entertainment clubs" do not sell sex: they rent rooms, sell drinks, and/or charge door fees. As in the 1920s, they do not formally touch women's earnings from sex, nor do they keep the women as "inmates". Police precincts still keep unofficial registry books of prostitutes, however, and these are updated when arregos are paid or negotiated, or on the very rare occasions that police raid an establishment (usually for political reasons or non-payment of the arrego).

This results in a situation where the women in the lower reaches of the Brazilian sex industry simultaneously have more autonomy, but no greater rights than their sisters in China, Italy, and the U.S. It is rare to see women "forced" into prostitution by anything other than economic need. One of Blanchette's sex-working informants expresses this economic pressure in the following manner, "My children are my pimps". As Ana Paula da Silva points out (da Silva, Blanchette, 2018) and Blanchette's fieldwork confirms, most women who sell sex in Rio shift in cycles through what da Silva calls the "triangle of women's work": poorly paid service economy jobs, traditional housekeeping with economic dependence on a male, and relatively well paid prostitution. Of the three positions, only prostitution offers some hope for capital accumulation or reasonable, independent improvement of the woman's socio-economic status. Sex-selling women are thus often seeking escape from abusive personal relationships, personified by violent husbands or boyfriends, or by abusive managers and bosses (who often sexually harass their female employees: Blanchette \& Da Silva, 2017). Prostitution holds out to them the possibility of achieving independent economic survival and even prosperity without being beholden to a man - ironically, by selling sex to men.

However, as one of Blanchette's 60 year old sex worker interlocutors points out, "There are two things you can't put on your CV: mom and whore". The longer a woman stays in the prostitution pole of the "woman's work triangle", or the more often she passes through it, the more likely she is to become permanently marked by its stigma - which in socially conservative, misogynistic Brazil can be considerable. Minimally, she is likely 
to be recorded as a prostitute in the police's "unofficially official" registries. The police and other third parties also hold the threat of "outing" a particular woman to her family or community, which can result in threats to her life, her custody of her children, or her ability to find other employment. Finally, there's what the women themselves call the "addiction" of prostitution, by which they mean that it is very hard to go back earning the minimum wage of 200 USD a month - or nothing at all, in the case of housewives - after earning upwards of five times that selling sex. Thus, the longer one sells sex, the harder it is to leave prostitution. At the same time, age and hegemonic standards of female beauty ensure that sex work is what sociologist Paul G. Cressey, in his classic study of the "taxi dance hall", calls a "decadent career" (Cressey, 1932), where every year passed in said line of work diminishes the worker's prospects and pay. Because of this, one of the common options for older prostitutes in Rio de Janeiro is to continue on in sex work as madams, managers, or brothel administrative personnel. This, in turn, puts them into personal relationships of reciprocity and control (a la Mauss' The Gift, 1950) with venue owners and the municipal authorities who ultimately profit from prostitution in Rio de Janeiro.

In the decades following the end of Brazil's military dictatorship (1985), police control over prostitution has often been exercised through third party "cut outs" (Blanchette, et al, in press). Locally known as the "militia", these paramilitary groups are generally formed by ex-police officers, firemen, soldiers, and other State security personnel, often owing allegiance to local politicians and having informal connections to State security forces. The response of the organized prostitutes' movement in Brazil in the face of this "privatization" of police control has been to call for the voluntary regulation of sex work, bringing prostitutes under Brazil's labor laws. This has received extreme reaction from certain sectors of the feminist movement in recent years, which sees such legislation as "legalizing pimps" (Piscitelli, 2012; Correa \& Olivar Nieto, 2010). Meanwhile, in 2018, Brazil elected a president who is widely associated with militia groups, leading to the sponsor of the regulation bill, Federal Deputy Jean Wyllys, to flee Brazil after multiple death threats and the murder of his colleague, Rio City Councilwoman Marielle Franco, by the new president's neighbor. At the same time, a bill is advancing through Congress, sponsored by the far Christian right, to criminalize the purchase of sex. Hence while control creep takes a different route in Brazil than in China, Italy, or the United States, it nonetheless exists as a powerful force in sex workers' lives.

\section{Case Study Two: China}

In 2010, rural migrant female sex workers, arrested in a massive police raid in Dongyuan, Guangdong province, were paraded down the street for public shame and open denigration (Qing 2010). Barefoot, these women were handcuffed and tied with long ropes like dogs, leashed and paraded by the police on the street for public spitting and public humiliation. Public shaming activities like this also took place in Hubei and Henan province respectively in 2010 and 2009. In Hubei province, police force in Wuhan city posted personal information such as the true names and ages of arrested rural migrant sex workers everywhere in the city from small alleys to large streets for public disgrace (Yu 2010). In Henan province, the police force in Zheng city publicized nude photos of female sex workers in the media for public denigration (Fu 2009). In one of the photos, a plain-clothed policeman violently pulled the hair of a sex worker, who was kneeling in front of him, naked, with arms across her chest, looking terrified and in pain.

Publicly vilifying and shaming rural migrant female sex workers epitomizes the stigmatization, marginalization, criminalization, and exclusion of rural migrant female sex workers from legitimate citizenship. Rural migrant women shoulder heavy historical baggage due to their rural origin. As a result of decades of prejudiced government policies against rural people, poverty and deprivation have driven 260 million rural people to cross the urban-rural border and enter the city. The household registration system (hukou) divides the population into urban "citizens" and rural/migrant people without urban residence permits, denied subsidized 
housing, children's education, health care, employment, and other benefits associated with urban residence permits (Goodkind and West 2002; Li and Piachaud 2006). This system, despite some reforms since the late 1990 , is deemed as "the most serious form of institutional exclusion against mainly rural residents" that produces "rural-urban apartheid" in China (Chan and Buckingham 2008, 583-587; Zheng 2015).

Despite rural migrants' immense contribution to the local and national economy, they still face severe institutional constraints (hukou) and social, cultural, and economic marginalization and stigmatization. It was reported that in 2003, a college graduate was arrested by the police for failing to show a temporary resident card, mandated for all rural migrants to stay legal in the city (Chen 2003). He was subsequently beaten to death at the repatriation center. Like him, rural migrants are often subject to police harassment and search for legal documentation, deportation or detention, wage withholding, reduction of payments, and social discrimination.

Rural migrants are categorized as backward and barbarian "outsiders" who are not only excluded by the state and urbanites, but also maltreated and blamed for social problems. Rural migrant women are portrayed in the media as perpetrators of crimes and vectors of diseases as well as victims (Zheng 2009b). They are also represented as both chaste virgins and promiscuous, licentious, and sexually unbridled women whose sexuality is perilous, threatening, vicious, and detrimental to the moral fabric of society (Zheng 2009a). In this politically, socially, and economically hostile and discriminatory urban environment, rural migrant women are forced into the lowest rung of the labor market. They commonly work as factory workers, domestic maids, waitresses, and garbage collectors. In order to support their rural family, some take on sex work instead of these exhausting, low-wage physical labor, which often times involves not only a withholding or severe deduction of wages, but also rape by employers (especially in the case of domestic work). Their entry into sex work was either through the introduction by friends, sisters, and cousins, or through their own solicitation at the underground brothels. To the women, sweatshops, withholding of wages, and rape associated with the alternative labor are more exploitative than sex work, which has more flexible hours and is much more lucrative (Zheng 2009b).

Police raids of the entertainment places often lead to arrests and detention of sex workers in labor camps in the name of rehabilitation. Many women Tiantian Zheng worked with were arrested by the police during Zheng's fieldwork. After the arrest, they were told that a fine of 5,00o yuan (\$833) would earn their release. If they failed to submit this fine, they would be detained at labor camps for rehabilitation (which often involves forced labor) from 6 months to 2 years. In 2010, the amount of fine generally remained the same, though a much higher fine of 10,00o yuan (\$1667) was reported in some cities (Pan and Huang 2011). One of the reasons that the police can willfully extort sex workers and proprietors to serve their own interests is because they possess the arbitrary power to arrest, fine, and punish the women without the need to involve the court or the criminal justice system. As a result, sex workers find it imperative to obey the demands of the police including providing free sexual services and informing on other sex workers, in exchange for impunity from police arrests and fines.

All the women in the low-tier karaoke bar in Zheng's research lived in the bar to avoid the housing discrimination against migrants without legal documentation. Living in the underground brothel subjects them to sudden, constant police raids. Constant police raids and the illegal status as rural migrant sex workers without any legal recourse are conducive to a violent working environment wherein women suffer mental stress and physical harms perpetrated by thugs, police, clients, and bar bouncers. There is no political representation of their interests or support network in the city to which they can turn. Despite the 2006 Law on AIDS Prevention and the State Council 2012 Proposal, condoms continue to be used as evidence of sex work during police raids and police harassment (Pan and Huang 2011). Sex workers are thus discouraged from carrying condoms to avoid police arrests and subsequent detention, circumventing their engagement in safe sex and increasing their vulnerability to sexually transmitted infections. 
Police raids also drive sex workers into dangerous, clandestine working environment. During Zheng's research, some sex workers chose to continue sex work during police raids, by following clients to their places. These unfamiliar, strange, and remote places such as rented apartments subjected the women to their clients' whim, including violence and unsafe sex. Others chose to return to the rural hometown as a hideout for several months until the police raids ended, when they found themselves in desperate economic deprivation. When they resumed sex work, the heavy financial loss precipitated them to engage in unsafe sex to offset the loss.

Zheng's research showed that the women employed a wide range of methods to thwart STIs, including emergency contraceptive pills, liquid condoms, and pre-sex antibiotic shots, which were not only ineffective, but also harmful in inducing infertility, heavy vomiting, irregular periods, severe abdominal pain, and frequent pregnancies and abortions (Zheng 2009b). Zheng's research at hospitals revealed that doctors were required by the police to relinquish the true names and information of patients with STIs, which was an effective way for the police to track down and arrest sex workers. Women in Zheng's research hence deliberately avoided these hospitals and visited low-quality, cheap, and unlicensed clinics, often operated by unqualified quack practitioners without formal or professional medical training. This kind of temporary symptom relief such as antibiotic shots often times leads to long-term physical suffering.

Without legal protection, women in Zheng's research found no alternative but to seek protective social networks with gangsters who offer protection against violence perpetrated by bar bouncers, clients, and other thugs (Zheng 2009a). As an exchange, the women provided free sexual services. Indeed, the illegal status of their work as well as their identity as rural migrants deprives them of any support network in the city. Their only option to cope with this hostile, stigmatizing, and marginalizing urban environment is to form a relationship with one or two gangsters such as skilled street fighters, formidable thugs, and ex-convicts who can be on their call to rescue them from impending physical assault, harassment, and violence perpetrated by clients and other gangsters. Control creep's totalizing force relies on systemic collusion between a wide range of socio-institutional, legal, and interpersonal forces to further exclude and stigmatise rural migrant women who sell sex in urban China.

\section{Case Study Three: Italy}

In Italy, the advancement of the control creep discussed in this article can be observed in particular in the past two decades. During this time, the landscape of prostitution in the country has undergone rapid transformations resulting, to a large extent, from the growing number of migrant sex workers, with the sparse available data indicating that non-Italian nationals represent the majority of those who sell sex in both indoor and outdoor sectors. Since the 1990s, hostile attitudes towards immigration and its purported association with criminality have been fueled by the visible presence of migrant women and, to a lesser extent, migrant men and trans women selling sex in public spaces. Perceived and represented as a nuisance and as a social and public health threat, "foreign prostitutes" have frequently been the target of widespread campaigns concerned with the defense of public decency, Italian values, children's innocence and women's honor (Danna 2004), and of the explicitly racist and anti-immigration attacks of the ever-strengthening xenophobic party Northern League (Crowhurst 2007). But, in the context of intensifying anti-sex trafficking international mobilizations, public hostility and vilification have also been concomitant with growing concerns over the exploitative living conditions of these new migrants and their potential for being victims of sex trafficking. It was in the 1990s that an extensive network of support organizations was formed and was later firmly established through a successful and internationally praised government-funded system of assistance for victims of sex trafficking introduced in 1998 (Andrijasevic 2010; Crowhurst 2006. Today, the conflicting yet dominant (Anderson \& 
O'Connell Davidson 2003 Aradau 2004) double identification of "foreign prostitutes" as dangerous illegal migrants who must be removed with repressive measures and as victims of sex trafficking who need to be assisted and potentially reintegrated into the community is a dominant paradigm in Italy (Crowhurst 2012).

Indeed, the elimination of both street prostitution and of sex trafficking has been identified as the objective of many local municipalities' so-called "anti prostitution ordinances", widely issued since the mid-199os by Italian Mayors across the country. These measures are mostly implemented with police raids during which hefty fines are issued to both clients and sex workers who, if undocumented, which is the case of many street sex workers, may end up being deported. Very rarely do these punitive initiatives contribute in any meaningful way to fighting sex trafficking or to reducing street prostitution in the longer term (CNCA 2009). Nevertheless, reflecting the key attributes of "control creep", they are normalized and justified as concrete and tough measures to eliminate the criminal and criminogenic activity of street prostitution, the exploitation of those involved in it, and to protect urban safety and citizens' wellbeing. They have therefore remained popular and recurrently adopted, often accompanied by hyperbolic media coverage which, on one hand, sensationalizes their alleged short-lived effects of 'urban cleansing' and 'victim salvation' (DiRonco 2018), whilst, on the other hand, it ignores their pervasive exclusionary effects on migrant women's wellbeing.

The data Isabel Crowhurst collected between 2002 and 2006 during extensive fieldwork with support organizations operating in the field of street prostitution across Italy reveals the extent of the damaging impact that these anti-street prostitution measures have on the lives of sex workers, as also evidenced by the few other studies and reports of their effects (CNCA 2009; Cittalia 2012). As many of Crowhurst's respondents lamented, consistent and repressive police raids had forced street sex workers to constantly change their working locations and travel great distances to work in less targeted, but also more secluded and dangerous areas. A report based on research carried out by a number of support organizations (CNCA 2009) states that to steer away from the police many sex workers have moved to unhealthy and overcrowded indoor premises. This has both increased competition and reduced earnings, resulting in sex workers having to work longer hours and take more risks, including not using condoms, to increase their dwindling profits. In an attempt to save money, some sex workers skip meals, or cannot afford to buy medicines and appropriate clothes for the cold winters, contributing to their deteriorating health conditions. Moreover, the constant fear of being raided, losing earnings, and being deported have a damaging impact on their mental health (CNCA 2009). Inevitably, as Crowhurst's respondents relayed to her, anyone perceived to be an institutional figure, including themselves, is viewed with suspicion, for fear that they may be colluding with the police. Mistrust and enhanced mobility compromise the capacity of support services to get to know and build trusting relationship with sex workers and to provide them with health and emotional assistance, to distribute condoms and to inform them about their rights and legal options. Police forces, including those operating in areas where constructive relationships had previously been established with support services and street sex workers, are now avoided and feared by the latter. One of Crowhurst's respondents told her that it was not uncommon for street sex workers to jump into the river flowing along the main road to avoid the police, or sometimes even to escape from moving police vans when they are escorted to police headquarters.

In 2008 the news that a Nigerian street sex worker was killed in a car accident trying to flee from a police raid (LuccioleOnline 2008) shed a less than triumphalist light on the effects of the punitive ordinances. It was in that same year that the grim circumstances of these repressive measures also reached national attention after an anti-prostitution raid did not go according to plans. The Mayor of a northern Italian city had arranged the raid as a media stunt to advertise his proactivity on the fight against street prostitution and its exploitation. However, the presence of the media during the police operations enabled the recording of allegedly abusive practices which generated strong public denunciation. During the raid, a Nigerian street sex worker, having unsuccessfully resisted being taken to the police headquarters, was locked up for the night in a 
security cell. Here, exhausted, she lay on the floor where she was photographed by one of the invited journalists (Robusti 2008). The events of the night were later reported in many national and international newspapers which displayed the shocking photograph of the woman lying semi-naked on the dusty floor of the barren police cell. Many politicians and professionals operating in the field of migrant prostitution expressed outrage at the mistreatment and violence that the woman appeared to have been subjected to, and condemned the raids as measures which further contribute to the vulnerability of and stigma attached to migrant street prostitutes in the country (La Repubblica 2008). Challenging this view as an ideological misrepresentation, the Mayor and other local authorities, making use of racialized stereotypes, referred to the woman in the picture as a recidivist prostitute who had been aggressive and had refused the assistance offered by the police and the possibility of being rescued from her street life (TV Parma 2012; La Repubblica 2008). They kept justifying the raids they had ordered, and reiterated their importance as effective measures to improve the safety of public spaces and to contribute to putting an end to the exploitation of migrant women in the sex industry and to give them back their dignity, self-respect and self-worth (ibid.).

This very specific event is extraordinary for the access that journalists were granted to it and for the ensuing media coverage that it received. It also provides insight into the contexts of the normal and normalized antistreet prostitution raids that are routinely carried out on the national territory and of some of their damaging effects. Despite this, the authorities who ordered the raid kept making sense of it as a necessary operation with both punitive and "salvific" aims and refused to acknowledge any reference to the abuse and violence inflicted and resulting from these practices. The evidence of the harms they cause and of the multiple levels of exclusions they reproduce, as also revealed in the previously mentioned public report (CNCA 2009), remain ignored as more anti-prostitution measures are issued and implemented year after year.

\section{Case Study Four: The United States}

Women arrested on prostitution-related charges in the United States disproportionately come from intergenerationally poor communities and struggle with addiction, precarious housing, compromised mental and physical health, interpersonal violence, and child custody arrangements (Dewey \& St. Germain 2017). Their arrests primarily stem from their high visibility as they solicit clients in neighborhoods dominated by the illicit drug economy, where they live and spend most of their time. The systemic and totalizing impacts of control creep in the United States, which has the world's highest incarceration rate (Enns 2016; U.S. Department of Justice 2017), among women in prostitution is particularly evident in the case of a Colorado legal statute, "Prostitution with Knowledge of AIDS," that imposes felony charges and prison sentences on HIV positive individuals who provide transactional sexual services.

Most street-involved women regard their involvement in street prostitution as a direct result of the significant economic need engendered by a drugs-prostitution-homelessness nexus described as "going hand-in-hand" (Sallman 2010). Many have grown up in a series of motel rooms and relatives' governmentsubsidized apartments not far from the neighborhood where they trade sex for money, and a number of Dewey's participants began turning tricks to buy food and other necessities for her siblings when a mother's or caregiver's drug addiction make her incapable of maintaining food stamps, stable housing benefits, and other government services available to the intergenerationally poor family. Entering prostitution as a minor is positively correlated with family members' substance abuse and African-American ethno-racial identity (Clarke, Roe-Sepowitz \& Fey 2012). The immediacy of meeting daily needs, caregiving obligations, and extremely limited income generation alternatives severely constrains women into a situation of "mutually reinforcing sex work and problematic drug use" (Cusick \& Hickman 2009). These already limited economic prospects only worsen following their release from prison, when the difficulties associated with criminal background checks 
by potential employers and the need to pay for drug testing and classes, with titles like "Anger Management" and "Parenting," as a condition of meeting parole requirements increased a woman's likelihood of re-incarceration. Many street-involved women leave jail or prison with no fixed address and a motel voucher for a few nights' accommodation in what police term "a known prostitution area" and where they have previously traded sex for money.

African American women are over-represented in street prostitution and statistically more likely than their peers of other ethno-racial identities to face sexual assault, police profiling, as well as overall higher rates of violence and arrest (Campbell et al. 2003; Reid 2011). The sex industry reflects racial stratification and segregation prevalent in other socioeconomic sectors of the United States, with African American women targeted by a wide array of intersectional harms that contribute to arrest and incarceration (Richie, 2012). "Just another crack whore, a walking stereotype" is how one participant characterized the way in which most criminal justice professionals, including police patrol officers view her. These realities have direct relevance for street-involved women's health, leading them to avoid disclosing involvement in prostitution to healthcare providers due to fear of judgment and, as other researchers have found, to face discontinuities in healthcare between correctional and free world settings (Sered \& Norton-Hawk 2013). Particularly for women living with HIV and involved in prostitution, positive serostatus is part of police records as well as criminal record as a result of her conviction for Prostitution with Knowledge of AIDS. The mental and physical stresses associated with spending long periods of time outdoors in very hot or very cold Rocky Mountain weather are exhausting, and yet many street-involved women avoid shelters because they are mixed gender and house residents of uncertain mental health status.

The extensive criminal record and stigmatization as sex workers and illicit drug users make most streetinvolved women avoid police contact, as they fear that any encounter with police may lead to being stopped, searched, and arrested or otherwise detained as part of what her peers term "walking while female" in a neighborhood dominated by the illicit drug economy and the street prostitution related to it. Such gender profiling, which has been documented by other researchers with respect to transgender women (e.g. Edelman 2011), contributes to low levels of trust in authority, so that women in street prostitution rarely report assaults to police and perpetrators act with impunity. Soliciting in less well-lit and less safe areas likewise reduces women's abilities to screen clients or insist on condom use, as other researchers have noted (Shannon et al. 2009). "People get left in dumpsters for a reason," one participant told Dewey of neighborhood gender dynamics that she hopes that her streetwise self-presentation and connections to men involved in criminalized activities can help her to counter, "you gotta have protection."

Unfortunately, such protection is often offered by men who are just as vilified by media representations and also facing their own battles with addiction, housing, and related issues. Enduring "tough on crime" media and political rhetoric in the United States as part of the War on Drugs continues to hypersexualize and demonize women in street prostitution as vectors of disease but also as victims of violence and abuse, rather than recognizing the tremendous agency they demonstrate on a daily basis (McCracken 2013). Social services available to street-involved women almost all have a faith-based mission to "redeem" or "rescue" her from her situation; court-mandated services, such as transitional housing that provides drug treatment, often takes a harsh punitive approach. Ghettoized living and working conditions are the result for street-involved women in a totalized, overpriced environment wherein everything - from motel accommodation to illicit drugs to food- operates in a cash economy sustained through prostitution and illicit drug use.

Daily encounters with police and the criminal justice system are status quo for street-involved women, who almost all engage in small-scale drug dealing with their clients, shoplifting, and other criminalized income generation ventures to meet their daily needs and manage their sometimes quite expensive addictions (Caputo 2008). Once arrested, as they typically have been many times before, a police patrol officer may ask 
a street-involved woman if she is being forced into prostitution but this eventuality reduces relative to the number of arrests and convictions a woman accrues, such that her entrenchment in the criminal justice system as a repeat offender indicates she is farther on the volitional "criminal" side of the victim/criminal continuum that characterizes criminal justice (and dominant cultural) approaches to prostitution. The criminalization of prostitution, homelessness, loitering in public, and other activities related to women's street involvement generates a fractious social context that encourages women to work as police informants in exchange for reduced criminal charges or sentencing, or to avoid arrest altogether.

\section{Discussion: A perfect storm of oppression}

The synchronous operations of control creep have widespread social support that endorses and, in the case of criminal justice and some social services actors, mandates treatment that stigmatizes and excludes sex workers. The politician who criminalizes sex work to garner the popular vote in support of "family values" or even "women's rights," the police officer tasked with arresting the very poor women who are trying to earn a living, and the sex worker rights activists whose efforts are thwarted or impeded by widespread support for criminalization all act as individuals within collusive systems that support sex workers' exclusion. The result is a perfect storm of oppression through which control creep manifests in six primary forms of exclusion.

Control creep's exclusionary effects squarely situate sex workers at the center of this perfect storm by targeting them as criminals while simultaneously exploiting their vulnerabilities as marginalized women with few socio-legal and other citizenship rights. Taken together, these exclusionary forces - in their totalizing economic, intersectional, health, safety, public vilification, and policing forms-position street-involved women within a vortex from which they find it very difficult to emerge. In this section we discuss more in details these six forms of exclusion, drawing on a combined analysis of our empirical data in conjunction with a survey of global prostitution research on these six dimensions. All six forms of exclusion intersect with one another in ways that have not been previously explored by researchers, who often focus on one or more aspects of these exclusions without consideration of how they operate contemporaneously as a whole. These exclusions derive from control creep's increasingly pervasive exercise of policies, modalities, and encounters that stigmatize and oppress sex workers in a systematic and totalizing manner.

\section{Control creep and its combined exclusionary forces}

Women's entry into sex work is often motivated by a lack of economic alternatives that offer similar income or flexibility (Plambech 2017; Sallmann 2010), a predicament which we identify as a manifestation of economic exclusion. Women who are treated as 'second class citizens' (as seen in the case of rural migrant women China), who are undocumented (migrant sex workers in Italy), or struggling with addiction and homelessness (in the US) tend to be further marginalized to sex industry sectors in which they have the least economic control, but which, as the Chinese example clearly showed, can be viewed and experienced as less exploitative and dangerous than other informal economy occupations. As the four country cases outlined above also show, many quality of work issues in the sex industry arise from the socio-legal sanctions that often accompany sex for sale, including stigmatisation, unpaid or unequally compensated labor, compromised health, limited social supports, and varying levels of state oversight (Adriaenssens et al. 2016). The US case also highlights the difficulties that sex workers can encounter in finding legal and/or less-stigmatised work when faced with criminal records, gaps in work histories, and being forced to hide their sex work activities in ways that can "trap" them in the industry even when they wish to leave (Cusick \& Hickman 2009). Some sex workers confront these restrictions by capitalizing on their experiential and insider knowledge. In some instances, they take on 
a managerial sex industry role that offers more power, control, and income with less invasive client contact than prostitution, such as becoming a madam (Cole 2006), or in other circumstances, as Dewey's work in the US shows, by acting as police informants to minimize, or avoid criminal justice sanctions. Sex workers clearly resist the operations of control creep even as its widespread impacts make it difficult to do so, just as police, social workers, and others exercise agency in their dealings with sex workers- even if in so problematic a gesture as accepting a bribe in exchange for not making an arrest.

A second form of exclusion we have identified -what we refer to as intersectional exclusion-involves the systemic impacts of structural racism, classism, and sexism in ways that contribute to the fact that in many local sexual economies, lighter skinned and more formally educated women earn more money in venues where they are far less likely to encounter police (Mahdavi 2010). In the US, we saw how racialized minorities dominate in lower-paid sex industry sectors, which they often enter at younger ages and under more disadvantageous labor circumstances, including limited control over their earnings, greater exposure to violence, and increased risk of arrest (Martin, Hearst \& Widome 2010). In Italy and China, migrant sex workers, both undocumented and not, may likewise struggle with forms of sexualization that reflect neocolonial processes, racist sentiments, and/or deeply ingrained prejudice against rural migrants (Ifekwunigwe 2004; Lam 2016). The social networks marginalised sex workers cultivate to negotiate these intersectional exclusions operate in complex ways, such as third party offers of assistance with navigating a new country in ways that migrants and/or local law may regard as exploitative (Verhoeven \& van Gestel 2017), or by seeking out 'protection' from men involved in criminalized activities. In contrast to these 'alliances', the sheer heterogeneity of transactional sexual services, significant differences between individuals who perform them, the divisive environment created by competition for clients, and, for some women, the psycho-social dynamics of addiction or undocumented status, further complicate activist organizing (Crago 2008; Zheng 2010).

National and municipal legislation, the presence or absence of sex workers' rights movements, and international legal and rights frameworks all impact on two further entwined forms of exclusion we identified: exclusions from healthcare services and safety (Overs and Hawkins 2011; Rekart 2005). Women may hesitate to disclose their involvement in transactional sexual activities to healthcare providers, or, as seen in the Italian case, to seek out for the assistance offered by outreach support services, missing out on their provision of much needed condoms and lubricants. In China, police confiscation of condoms as evidence of the intent to engage in prostitution results in further compromising women's health and safety and fostering their mistrust of police, as indeed reported in many studies across the globe (Scorgie et al. 2013; Shields 2012).

Unaffordable healthcare costs, stigmatising treatment, fear of deportation, travel distance, high costs, and wait times may prompt sex workers to delay or avoid medical care in favor of self-treatment (Porras et al. 2008; Richter 2013). Working in less well-lit and less safe areas due to fears of being stopped, searched, and detained creates a culture of fear that decreases sex workers' abilities to negotiate condom use and seek services (Kurtz et al. 2005). This stress impacts women's relationships with intimate partners, who may suffer from jealousy, a desire to exercise sexual control, or coercion into sex work to support a partner's addiction, all of which occurs in tandem with client violence and police abuse of authority to threaten women's safety (Ulibarri et al., 2010).

Social exclusion through public vilification emerges clearly from the data presented in all four countries and enables assaults on sex workers with impunity. Indeed, murder rates are higher among women in prostitution vis-à-vis their peers outside the sex industry (Salfati et al. 2008). Mass media typically represent sex workers as either vulnerable subjects who must be protected from sexual exploitation or as pariahs who threaten the moral order and health of societies (Doezema 2010). However, as seen in the Italian case, these two opposite representations are often conflated, with migrant sex workers depicted and vilified as both threatening 'others' and as burdensome victims for the state. In China, the shocking images of mis-treated rural sex workers served to incite public hatred towards them as non-deserving citizens to be publicly shamed and punished. 
Just as in the US the public demonization of female street sex workers should be understood in the context of the highly publicized 'war on drugs', so too in China and Italy, and indeed beyond these countries, these troubling yet pervasive negative representations serve to normalize punitive and often violent state interventions as 'just' and much deserved by these vilified populations.

Finally exclusion through policing is conspicuous in our data. The law plays a significant role in constituting the social organisation of commercial sex (Scoular 2015), with sex workers adopting an array of approaches to avoid arrest or other negative police encounters (Dewey \& St. Germain 2014). As seen, in Italy, at least one migrant sex worker is known to have died trying to escape from the police, and in all four cases, sex workers have to compromise their safety by agreeing to follow clients to dangerous places in order to avoid the police. Sex workers in the most visible and public sex industry sectors are most likely to face public nuisance complaints and police harassment, and police raids, even when allegedly aimed at 'liberating' victims, cause further harms to a population which, for fear of them, is forced to operate in even more vulnerable and precarious conditions.

The perfect storm of oppression created through control creep actively works to impel and contain marginalized women, who already struggle with limited citizenship and other rights, within low-autonomy sex industry sectors. Our analysis of the stratifications and differentiations inherent to control creep among women in low-autonomy sex industry sectors emphasizes how citizenship more traditionally understood, i.e. related to holding a passport (or not), is just one of the many more complex factors that coalesce to limit sex workers' recognition and access to rights and protection. Socioeconomically excluded, stigmatised, and policed as a result of intersectional factors that include sexism, racism, and classism, women in low-autonomy sex industry sectors face numerous mutually reinforcing harms to their health, safety, and abilities to selfactualize. We have acknowledged the deeply rooted and pervasive impacts of control creep as they manifest in six forms of exclusion that operate to limit or deny recognition and institutional and social protection of multiple intimate life arrangements -including partnerships, parenting, sexual identities and practices, and caregiving - and bodily autonomies, including access to health care, abortion and freedom to commodify one's body and bodily services (Roseneil et al. 2012). In all these instances, the wide-ranging and far-reaching impacts of control creep further marginalize the most vulnerable sex workers. In so doing, control creep's effects delegitimize the agency of women in sex work by reducing them to people devoid of rights and the ability to speak for themselves, even though sex workers clearly exercise resistance against control creep's impacts.

\section{Conclusion}

Using examples from our empirical research with women in policed, stigmatised, and low-autonomy sex industry sectors in China, Italy and the United States, we have argued that control creep facilitates a perfect storm of oppression. We identified six prevalent forms of exclusion that result from control creep's seepage of increasingly diversified socio-legal control mechanisms into the everyday lives of women in prostitution and the various ways that the women navigate their victim/criminal status to internalize and/or mobilize these exclusions. Control creep has great utility as a theoretical-analytical concept because it captures how systematic and interpersonal modalities of control - as are apparent in the economic, intersectional, health, safety, public vilification, and policing-related exclusions-result in a wide-ranging set of harms for women in these sex industry sectors. While our analysis is specific to the sex industry, control creep has direct implications for scholars interested in questions of citizenship and the processes of state and socio-institutional legitimation that inform such questions.

Control creep's authoritarian force relies on ignorance of the sex industry's knowns, unknowns, and complexities to ensure that those who contribute to its diffusion solidify their position of power as epistemically superior subjects who 'know better'- all too often, by willfully ignoring evidence. In each of our field sites, 
evidence overwhelmingly suggests that control creep itself - rather than labor conditions within the sex industry - instigates and supports the six forms of exclusion identified. Migrant sex workers in Italy are subject to ordinances and socio-legal measures that, while ostensibly designed to reduce exploitation and improve public safety, derive from morally loaded and racist assumptions about both migrants and the sex industry. Rural migrant women who sell sex in urban China do so because they lack urban residence permits, face arrest, police harassment and extortion, and unsafe working conditions as a result of systemic collusion between socio-legal forces that stigmatize rural people and exclude them from the benefits of urban residence. High rates of arrest and incarceration among street-involved women in the United States result in interlinked forms of oppression through the criminalization of homelessness, addiction, and prostitution, which occurs in tandem with significant discrimination against individuals with criminal records. In all four instances, legal, social, and interpersonal forces collude in the production and reinforcement of control creep.

Also worrisome to the authors, as academics engaged with politically organized street- and brothel-level sex workers, has been the effects control creep has had on the possibilities for producing scientific, primarysourced based data on the sex working populations most affected by control creep. It often appears to us that the law enforcement and social assistance actors who are the "front line soldiers" in the colonial appropriation of women's lives and bodies described above agree with prohibitionist activist and journalist Julie Bindel's ${ }^{3}$ affirmation that if she had a gun and a single bullet, she would not shoot a pimp, but rather a sex work researcher (Agustin, 2010).

In countries like the United Kingdom, comments such as Bindel's might be dismissed as mere hyperbole, but in nations like Brazil and China, it is not unknown for academics who research "improper" topics to disappear. Even in the relatively liberal U.S., rhetoric such as that espoused by Bindel, when operationalized by the new laws ${ }^{4}$ supporting what Susan Dewey and Tonia St. German calls "the Alliance" (i.e. the interlocking, self-supporting and -justifying system of police repression and social service "rehabilitation" that traps sex working women in a state of quasi-permanent State tutelage: Dewey \& St. Germain: 2016) has resulted in the cancelation of sex-worker/researcher symposiums and conferences such as the Desireé Alliance Conference (Trouble, C. 2018).

Brazil is a particularly dangerous case in this respect. The new government led by the extreme right under President Jair Bolsonaro has declared war on gender studies in schools and universities and, in particular, considers research into sex work to be "shameful". While Bolsonaro has made comments that have been interpreted as encouraging (heterosexual) sex tourism, he has also put what's left of the federal human rights secretariat - and, in particular, its anti-human trafficking committee - under the control of conservative evangelical Christians. The Bolsonaro family is widely alleged to have extensive ties to paramilitary militias in Rio de Janeiro, which have long controlled many of the city's brothels. While it is still too early to say what the outcomes of the Bolsonaro presidency will be for sex workers, Blanchette and his team of co-researchers have been documenting a steady, solid growth of militia activities and control in Rio de Janeiro's commercial sexscape, aided and abetted by police interventions.

In such a global scenario, international solidarity between sex workers, researchers, and their allies becomes even more important. This, however, is being undermined by the rhetoric of prohibitionist authors such as Julie Bindel in the global north and, particularly, in the Anglo-sphere. One only has to look at how Amnesty International's meticulously researched report into the health and human effects of sex work

\footnotetext{
3 Bindel is an anti-sex work, anti-trans- self-described "radical feminist" who has written extensively in the Anglo-sphere, supporting the criminalization of the purchase of sex and the rehabilitation (forced, if necessary) of sex workers, most notably for the British newspaper The Guardian. Currently, she is one of the most well-known voices writing in the English language in favor of the use of police power to "solve the problem of prostitution".

4 And here we must highlight Donald Trump's newly enacted FOSTA-SESTA law, which effectively criminalizes any on-line discourse that "favors" prostitution (see Godwin, 2018).
} 
(Amnesty International, 2016) was greeted with a chorus of reprobation among U.S. and Western European feminist and faith-based groups to see this undermining in action. It is important to note here that this outcry was not due to any supposed methodological errors on Amnesty's part, but was simply due to the report's conclusions that sex work should be completely decriminalized as a health and human rights measure. In this case, one can see that even elements of the so-called "left" seem to be fully in favor of control creep, as long as it doesn't affect them, personally. Particularly problematic, in this respect, has been the position of certain feminists from the global north that the so-called "Swedish Model" (i.e. the criminalization of prostitution) be unilaterally and immediately exported to countries like Brazil where the police, in conjunction with paramilitary militia groups, directly administer prostitution (Blanchette, Mitchell, \& Murray, 2017).

A vibrant body of literature already affirms that decriminalizing prostitution offers women in sex work with greater control of their working conditions while reducing some aspects of the stigmatization and exclusion they face. Such work demonstrates positive associations between decriminalization and increased access to healthcare and safer working environments among sex workers (Rekart 2005; UNAIDS 2012), with sex workers in decriminalized contexts reporting fewer instances of delaying or abstaining from healthcare due to stigmatizing treatment or fear of punishment (Overs and Loff 2013). This work also emphasizes how the law functions as a blunt instrument that is at best poorly equipped, and often entirely unable, to effectively account for the nuances that characterize transactional sexual encounters in practice (Wahab \& Panichelli 2013). Our analysis and theoretical-analytical articulation of control creep echoes this literature by emphasizing the forms of exclusion enabled and even fostered by prostitution's criminalization.

Submitted: March 10, 2020

Accepted: August 20, 2020

\section{References}

ADRIAENSSENS, S.; GAROFALO GEYMONAT, G.; \& OSO, L. 2016. "Quality of Work in Prostitution and Sex Work". Sociological Research Online, 21(4): pp 9-21.

AGUSTIN, L. 2010. “Important enemies: Hating sex work academics or hating research?” The Naked Anthropologist. At: https:/|www.lauraagustin.com. Accessed on: 11.9.2017.

AMAR, P. 2013. The Security Archipelago: Human Security States, Sexuality Politics, and the End of Neoliberalism. Durham, N.C.: Duke University Press.

ANDERSON, Bridget; O'CONNELL DAVIDSON, Julia. "Is trafficking in human beings a demand driven? A multi-country pilot study". International Organization for Migration (IOM), 2003. p.7-9

ANDRIJASEVIC, Rutvica. 2010. Migration, Agency and Citizenship in Sex Trafficking. London: Palgrave.

ARADAU, C. 2004. "The Perverse Politics of Four-letter Words: Risk and Pity in the Scrutinisation of Human Trafficking". Millenium: Journal of International Studies, 33(2): 251-77.

BLANCHETTE, T.G.; DA SILVA, A.P. 2017. "Sympathy for the Devil: Pimps, Agents and Third Parties Involved in the Sale of Sex in Rio de Janeiro". In: Horning, A.; et al. (Orgs.) Third Party Sex Work and "Pimps" in the Age of Anti-Trafficking. New York: Springer.

BLANCHETTE, T.G; MITCHELL, G.; MURRAY, L. 2017 "Discretionary Policing, or the Lesser Part of Valor: Prostitution, Law Enforcement, and Unregulated Regulation in Rio de Janeiro's Sexual Economy”. Criminal Justice and Law Enforcement Annual: Global Perspectives, 7: 31-74. 
BLANCHETTE, T.G.; SCHETTINI, C. 2017. “Sex Work in Rio de Janeiro: Police Management Without Regulation”. In: Garcia, M.R., Van Voss L.H, Van Nederveen Meerkerk, E. orgs. Sex Sold in World Cities: 160os-200os. Leiden, The Netherlands: Brill

CAMPBELL, R.; AHRENS, C.; SEFL, T.; \& CLARK, M. 2003. "The Relationship between Adult Sexual Assault and Prostitution: An Exploratory Analysis". Violence and Victims, 18(3): 299-317.

CAPUTO, G. 2008. Out in the Storm: Drug-addicted Women Living as Shoplifters and SexWorkers. Boston: Northeastern University Press.

CARVER, A. 2014. "Creep and Normalization: Exploring a Strategy of Social Control". Critical Criminology, 22: 419-432.

CHAN, K.W. and BUCKINGHAM, W. 2008. "Is China Abolishing the Hukou System ?” The China Quarterly, $195,582-606$

CHEN, F. 2003. "Bei Shourongzhe Sunzhigang Zhisi/The Death of Sun Zhigang During Repatriation". Nanfang Dushi/South Metropolitan Newspaper, Nov. 7. s/n, s/p.

CHAUMONT, J.M.; GARCIA, M.R.; SERVAIS, P. 2017 Trafficking in Women 1924-1926 - The Paul McKinsie Reports for the League of Nations. Vienna: United Nations.

CHUANG, J. 2014. "Exploitation Creep and The Unmaking of Human Trafficking Law". The American Journal of International Law, 108(4): 609-649.

CITTALIA (Fondazione Anci Ricerche). 2012. Per una Citta Aicura. Dalle Ordinanze agli Atrumenti di Pianificazione e Eegolamentazione. Retrieved from: http://www.cittalia.it/images/file/Cittalia pubblicazione_Per\%2ouna\%2ocitta\%2osicura\%281\%29.pdf

CLARKE, R. J.; CLARKE, E. A.; ROE-SEPOWITZ, D.; \& FEY, R. 2012. "Age at Entry into Prostitution: Relationship to Drug Use, Race, Suicide, Education Level, Childhood Abuse, and Family Experiences". Journal of Human Behavior In The Social Environment, 22(3): 270-289.

CNCA. 2009. Ordinanze Anti-Prostituzione. Retrieved from: http://www.fuoriluogo.it/sito/home/ mappamondo/europa/italia/rapporti_e_ricerche/prostituzione_rapportoeffettiordinanze.pdf

COLE, J. 2006. "Reducing the Damage: Dilemmas of Anti-trafficking Efforts among Nigerian Prostitutes in Palermo". Anthropologica, 48(2): 217-228.

CORREA, Sonia \& OLIVAR, José Miguel Nieto. 2010. The politics of prostitution in Brazil between "state neutrality" and "feminist troubles". Mimeo.

CRAGO, A. 2008. Our Lives Matter: Sex Workers Unite for Health and Human Rights. New York: Open Society Institute.

CRESSEY, Paul. 1932. The Taxi-Dance Hall: A Sociological Study in Commercialized Recreation and City Life. University of Chicago Press.

CROWHURST, Isabel. 2006. «The provision of protection and settlement services for migrant women trafficked for sexual purposes: the case of Italy». In: Trafficking \& the Global Sex Industry. Editors: Amir, D. and Beeks, K.. London: Lexington Books. Pp.217- 236

CROWHURST, Isabel. 2007. The 'foreign prostitute' in contemporary Italy:gender, sexuality and migration in policy and practice. PhD Dissertation in Philosophy, University of London. London.

CROWHURST, Isabel. 2012. "Caught in the victim/criminal paradigm: Female migrant prostitution in contemporary Italy.» Modern Italy. 17 (4), 493-506

CUSICK, L. \& HICKMAN, M. 2009. “'Trapping' in Drug Use and Sex Work Careers”. Drugs:Education, Prevention \& Policy, 12(5): 369-379.

DANNA, D. 2004. "Italy: The Never-ending Debate". In: J. Outshoorn (ed.), The Politics of Prostitution. Cambridge: Cambridge University Press. pp. 165-184. 
DEJ, E. \& KILTY, J. 2012. “Criminalization Creep: A Brief Discussion of the Criminalization of HIV/AIDS Nondisclosure in Canada". Canadian Journal of Law and Society, 27(1):55-66.

DEWEY, S.; CROWHURST, I.; \& IZUGBARA, C. 2019. The Routledge International Handbook of Sex Industry Research. London: Routledge.

DEWEY, S.; ST. GERMAIN, T. 2014. "It depends on the cop:" Street-based sex workers' perspectives on police patrol officers." Affilia 29 (4), 389-403

DEWEY, S.; ST. GERMAIN, T. 2016. Women of the Street: How the Criminal Justice-SociL Services Alliance Fails Women in Prostitution. New York: New York University Press.

DIRONCO, A. 2018. "Disorderly or Simply Ugly? Representations of the Local Regulation of Street Prostitution in the Italian Press and their Policy Implications". International Journal of Crime, Law and Justice, 52: 10-22.

DITMORE, M. \& THUKRAL, J. 2012. "Accountability and the Use of Raids to Fight Trafficking”. AntiTrafficking Review, 1: 134-148.

DOEZEMA, J. 2010. Sex Slaves and Discourse Masters: The Construction of Trafficking. London: Zed Books.

ECCLESTONE, K. 2017. “Changing the Subject of Education? A Critical Evaluation of 'Vulnerability Creep' and its Implications". Social Policy \& Society, 16(3): 443-456.

EDELMAN, E. 2011. “'This Area has been Declared a Prostitution Free Zone': Discursive Formations of Space, the State, and Trans 'Sex Worker' Bodies”. Journal of Homosexuality, 58(6-7): 848-64.

ELLISON, G. 2015. "Criminalizing the Payment for Sex in Northern Ireland: Sketching the Contours of a Moral Panic". British Journal of Criminology, 57: 194-214.

ENNS, P. 2016. Incarceration Nation: How the United States Became the Most Punitive Democracy in the World. Cambridge: Cambridge University Press.

FOX, D. 2014. "Interest Creep". George Washington Law Review, 82(2): 273-357.

FU, Z. 2009. "Maiyinnv Luozhao Bei Gongbu Yinzhiyi/Nude Pictures of Sex Workers was Publicized”. Hebei Qingnian Bao/Hebei Youth Newspaper, November 4. S/n, S/p.

GOODKIND, D. \& WEST, L. 2002. “China’s Floating Population: Definitions, Data and Recent Findings”. Urban Studies, 39(12): 2237-2250.

GODWIN, M. 2018. “Why Internet Advocates are Against the Anti-Sex Trafficking Bill”. Slate. https:|/slate. com/technology/2018/03. Accessed on: 21.9.2018.

GRAHAM, L. 2017. "Governing Sex Work Through Crime: Creating the Context for Violence and Exploitation". The Journal of Criminal Law, 81(3): 201-216.

HASLAM, N. 2016. “Concept Creep: Psychology's Expanding Concepts of Harm and Pathology”. Psychological Inquiry, 27(1): 1-17.

IFEKWUNIGWE, J. 2004. “Recasting 'Black Venus' in the New African Diaspora”. Women's Studies International Forum, 27: 397-412.

JANHSEN, S. \& SKILBREI, M-L. 2017. "Leaving No Stone Unturned: The Borders and Orders of Transnational Prostitution”. British Journal of Criminology, 58(2): 255-72.

KURTZ, S.; SURRATT, H.; KILEY, M.; \& INCIARDI, J. 2005. "Barriers to Health and Social Services for Streetbased Sex Workers". Journal of Health Care for the Poor and Underserved, 16(2): 345-361.

LA REPUBBLICA. 2008. "Foto Choc". Vignali: Tutto Regolare. August 13. Retrieved from: http://parma. repubblica.it/dettaglio/La-foto-della-vergogna-ecco-come-stata-scattata/1501302

LAM, E. 2016. "Inspection, Policing, and Racism: How Municipal By-laws Endanger the Lives of Chinese Sex Workers in Toronto". Canadian Review of Social Policy, 75: 87-112.

LI, B.; PIACHAUD, D. 2006. "Urbanization and Social Policy in China”. Asia-Pacific Development Journal, $13(1): 1-24$. 
LUCCIOLEONLINE. 2008. "Retata di Polizia Finisce con la Morte di una Ragazza Nigeriana".Retrieved from http:/|www.lucciole.org/content/view/392/14/

MAHDAVI, P. 2010. "Race, Space, Place: Notes on the Racialisation and Spatialisation of Commercial Sex Work in Dubai, UAE". Culture, Health \& Sexuality, 12(8): 943-954.

MARTIN, L.; HEARST, M.; \& WIDOME, R. 2010. "Meaningful Differences: Comparison of Adult Women Who First Traded Sex as a Juvenile Versus an Adult". Violence Against Women, 16(11): 1252-1269.

MAUSS, Marcel. 1950. The Gift: The Form and Reason for Exchange in Archaic Societies. London: W.W. Norton.

MCCRACKEN, J. 2013. Street Sex Workers' Discourse: Realizing Material Change Through Agential Choice. New York: Routledge.

MUNRO, V. 2006. "Stopping Traffic? A Comparative Study of Responses to the Trafficking in Women for Prostitution". British Journal of Criminology, 46: 318-333.

MUSTO, J. 2016. Control and Protect: Collaboration, Carceral Protection, and Domestic Sex Trafficking in the United States. Berkeley: University of California Press.

O'CONNELL DAVIDSON, J. 2006. “Will the Real Sex Slave Please Stand Up?" Feminist Review, 83(1): 4-22.

OVERS, C.; HAWKINS, K. 2011. "Can Rights Stop the Wrongs? Exploring the Connections Between Framings of Sex Workers' Rights and Sexual and Reproductive Health". BMC International Health \& Human Rights, 11(Suppl. 3): S6.

OVERS, C.; LOFF, B. 2013. “The Tide Cannot be Turned Without Us: Sex Workers and the Global Response to HIV". Journal of the International AIDS Society, 16: 1-6.

PAN, S.; HUANG, Y. 2011. "Evaluation of the Effect of 2010 Massive Police Raids/Nian Dasaohuang Xiaoguo de Pinggu." In: S. Pan (ed.), Rights and Multidimension: Essays from The Third International Symposium on Sexual Research in China/Quanli Yu Duoyuan: Disanjie Xingyanjiu Guoji Yantaohui Lunwenji. Beijing: The Center for Disease Control. pp. 12-35.

PEREIRA, Armando Santos. 2003 [1967]. Sexo e Prostituição. Rio de Janeiro: Gráfica Record Editôra.

PHOENIX, J. 2009. Regulating Sex for Sale. Bristol: Policy

PHOENIX, J. 2017. “Prostitution and Sex Work”. In: A. Liebling, S. Maruna \& L. McAra(eds.), The Oxford Handbook of Criminology, $6^{\text {th }}$ edition. Oxford: Oxford University Press. pp. 685-703.

PICKERING, S.; HAM, J. 2014. "Hot Pants at the Border: Sorting Sex Work from Trafficking”. British Journal of Criminology, 54: 2-19.

PISCITELLI, Adriana. 2012. "Feminismos y prostitución en Brasil: una lectura a partir de la antropología feminista". Cuadernos de antropología social, No.36: 11-31.

PLAMBECH, S. 2017. "Sex, Deportation and Rescue: Economies of Migration among Nigerian Sex Workers". Feminist Economics, 23(3): 134-159.

PORRAS, C.; SABIDÓ, M.; FERNÁNDEZ-DÁVILA, P.; FERNÁNDEZ, V.; BATRES, A.; \& CASABONA, J. 2008.

"Reproductive Health and Healthcare among Sex Workers in Escuintla, Guatemala". Culture, Health \& Sexuality, 10(5): 529-538.

QING, X. 2010. "Dai Xiaojie Youjie Shizhong/Dongyuan Police Raids, Public Parade of Arrested Sex Workers". Xinhua Wang/Xinhua net. July 18. S/n. S/p.

RATHOD, J. 2015. “Crimmigration Creep: Reframing Executive Action on Immigration”. Washburn Law Journal, 55: 173-188

REID, J. 2011. “An Exploratory Model of Girl's Vulnerability to Commercial Sexual Exploitation in Prostitution". Child Maltreatment, 16(2): 146-157.

REKART, M. 2005. “Sex-work Harm Reduction”. Lancet, 366: 2123-34.

RICHIE, B. 2012. Arrested Justice: Black Women, Violence, and America’s Prison Nation. New York: New York University Press. 
RICHTER, M. 2013. "Characteristics, Sexual Behavior and Access to Healthcare for Sex Workers in South Africa". Afrika Focus, 26(2): 165-176.

ROBUSTI, M. 2008. “La Foto della Vergogna ecco com'e`Stata Scattata”. La Repubblica. Retrieved from: http:// parma.repubblica.it/dettaglio/La-foto-della-vergogna-ecco-come-stata-scattata/1501302

ROSENEIL, S.; HALSAA, B.; \& SUMER, S. 2012. "Remaking Citizenship in Multicultural Europe: Women's Movements, Gender and Diversity”. In: B. Halsaa; S. Roseneil \& S. Sumer (eds.), Remaking Citizenship in Multicultural Europe. London: Palgrave. Pp. 1-20.

SALFATI, C.; JAMES, A.; \& FERGUSON, L. 2008. "Prostitute Homicides: A Descriptive Study”. Journal of Interpersonal Violence, 23(4): 505-543.

SALLMAN, J. 2010. “'Going Hand-in-Hand:' Connections Between Women's Prostitution and Substance Use". Journal of Social Work Practice in the Addictions, 10(2): 115-138.

SANDERS, T. \& CAMPBELL, R. 2014. "Criminalization, protection and rights: Global tensions in the governance of commercial sex." Criminology \& Criminal Justice, Volume: 14 issue: 5, pp. 535-548 SCHETTINI, Cristiana. 2006. "Que Tenhas Teu Corpo": Uma história social da prostituição no Rio de Janeiro das primeiras décadas republicanas. Rio de Janeiro: Arquivo Nacional.

SCORGIE, F.; VASEY, K.; HARPER, E.; RICHTER, M.; NARE, P.; MASEKO, S.; \& CHERSICH, M. 2013. "Human Rights Abuses and Collective Resilience Among Sex Workers in Four African Countries: A Qualitative Study". Globalization \& Health, 9: 1-13.

SCOULAR, J. 2015. The Subject of Prostitution: Sex Work, Law, and Social Theory. London: Routledge.

SCOULAR, J.; CARLINE, A. 2014. "A Critical Account of a 'Creeping Neo-abolitionism': Regulating Prostitution in England and Wales". Criminology \& Criminal Justice, 14(5): 6o8-626.

SCOULAR, J.; O'NEILL, M. 2007. "Regulating Prostitution: Social Inclusion, Responsibilization, and the Politics of Prostitution Reform". British Journal of Criminology, 47: 764-778.

SERED, S.; NORTON-HAWK, M. 2013. "Criminalized Women and the Healthcare System: The Case for Continuity of Services". Journal of Correctional Health Care 19(3): 164-177.

SHANNON, K.; STRATHDEE, S.; SHOVELLER, J.; RUSCH, M.; \& TYNDALL, M. 2009. "Structural and Environmental Barriers to Condom Use Negotiation with Clients among Female Sex Workers: Implications for HIV-prevention Strategies and Policies.” American Journal of Public Health, 99: 659-665. SHIELDS, A. 2012. Criminalizing Condoms: How Policing Practices Put Sex Workers and HIV Services at Risk in Kenya, Namibia, Russia, South Africa, the United States, and Zimbabwe. New York: The Sexual Health and Rights Project of the Open Society Foundations.

SILVA, Ana Paula da \& BLANCHETTE, Thaddeus Gregory. "Por amor, por dinheiro? Trabalho (re) produtivo, trabalho sexual e a transformação da mão de obra feminina”. Cad. Pagu [online]. 2017, n.50 [cited2020-10-27], e175019. Available from: $<$ http://www.scielo.br/scielo.php?script=sci_ arttext\&pid=S0104-83332017000200314\&lng=en\&nrm=iso .

SIMON, J. 2007. Governing through Crime: How the War on Crime Transformed American Democracy and Created a Culture of Fear. Oxford: Oxford University Press.

TROUBLE, C. 2016. "Largest Sex Worker Conference in the U.S. is Canceled Admid FOSTA Fears". Vice. https://vice.com/en_us/article/wjbkpg. Accessed on 21.09.2018.

TV PARMA. 2012. 'L'assessore Monteverdi e la Retata Anti-prostituzione'. Retrieved from: http://www. gazzettadiparma.it/mediagallery/video/1525/L\%26039\%3Bassessore_Monteverdi_e_la_retata_antiprostituzione.html

ULIBARRI, M.; STRATHDEE, S.; LOZADA, R.; MAGIS-RODRIGUEZ, C.; AMARO, H.; O'CAMPO, P.; \& PATTERSON, T. 2010. "Intimate Partner Violence Among Female Sex Workers in Two Mexico-U.S. 
Border Cities: Partner Characteristics and HIV Risk-Behaviors as Correlates of Abuse.”. Psychological Trauma: Theory, Research, Practice and Policy, 2: 318-325.

UNAIDS/Joint United Nations Programme on HIV/AIDS. 2012. UNAIDS Guidance Note on HIV and Sex Work. Geneva: UNAIDS. Retrieved from: http://www.unaids.org/sites/default/files/sub_landing/files/JC2306_ UNAIDS-guidance-note-HIV-sex-work_en.pdf

U.S. Department of Justice Bureau of Justice Statistics. 2017. “Total Correctional Population”. Retrieved from: https://www.bjs.gov/index.cfm?ty=tp\&tid=11

VERHOEVEN, M.; VAN GESTEL, B. 2017. "Between Visibility and Invisibility: Sex Workers and Informal Services in Amsterdam". Feminist Economics, 23(3): 110-133.

WAHAB, S.; PANICHELLI, M. 2013. "Ethical and Human Rights Issues in Coercive Interventions with Sex Workers". Affilia: Journal of Women \& Social Work, 28(4): 344-349.

YU, X. 2010. "Wuhan Jingfang Shiming Baoguan Piaochang Maiyin Renyuan/Wuhan Police Exposed Sex Workers' True Names and Relevant Information". Xinhua Wang/Xinhua net. July 17. s/n, s/p.

ZHENG, Tiantian. 2009a. Ethnographies of Prostitution in Contemporary China : Gender Relations, HIV/AIDS, and Nationalism. London: Palgrave.

ZHENG Tiantian. 2009b. Red Lights: The Lives of Sex Workers in Postsocialist China. Minneapolis and London: University of Minnesota Press.

ZHENG, Tiantian. 2010. "Complexity of female sex workers' collective actions in postsocialist China." Wagadu, v.8:34-45.

ZHENG, Tiantian. 2015. Sex Workers and Criminalization in North America and China: Ethical and Legal Issues in Exclusionary Regimes. New York: Springer.

Susan Dewey

Professor of Criminology \& Criminal Justice, University of Alabama

https://orcid.org/oooo-0003-1584-5260

Email:scdewey@ua.edu

Isabel Crowhurst

Senior Lecturer, University of Essex

https://orcid.org/oooo-0001-8125-7147

Email: icrow@essex.ac.uk

\section{Tiantian Zheng}

SUNY Distinguished Professor, SUNY Cortland

https://orcid.org/oooo-0001-6268-6974

E-mail:Tiantian.Zheng@cortland.edu

\section{Thaddeus Blanchette}

Professor of Anthropology, Biodiversity and Sustainability Institute, Federal University of Rio de Janeiro, Macaé https://orcid.org/oooo-0002-8828-3943

Email: thaddeus.blanchette@gmail.com 